\title{
PENYULUHAN PEMASARAN DAN PELATIHAN INOVASI PANGANAN HORTIKULTURA DESA NAGROG CICALENGKA (JAWA BARAT)
}

\author{
R. Fenny Syafariani \\ Universitas Komputer Indonesia \\ r.fenny.syafariani@email.unikom.ac.id
}

Andri Sahata Sitanggang

Universitas Komputer Indonesia

sahataandris@gmail.com

\begin{abstract}
ABSTRAK
Menciptakan inovasi pada panganan Hortikultura pertaniaan adalah hal yang sangat penting untuk meningkatkan nilai penjualan dan memasarkannya secara global adalah salah satu keunggulan yang dapat diperoleh dalam meningkatkan kesehiahteraan para petani hortikultura, dengan adanya pelatihan dan penggunaan sistem informasi pemasaran dapat membantu juga para petani dalam membuat alternatif dalam mata pencaharian saat ini sedang dijalankan. Kegiatan inovasi pelatihan pangan hortikuluta di Desa Nagrok adalah wujud dari penerapan teknologi yang ada pada UndangUndang Nomor 12 Tahun 2012 tentang Pendidikan Tinggi, sehingga masyarakat desa Nagrok dapat meningkatkan kesejahteraan hidup, inovasi yang dilakukan meliputi pelatihan pasta dan dodol kacang merah. Selain Pelatihan yang diadakan yang dibutuhkan oleh Desa Nagrok adalah satu media yang membantu dalam memasarkan prodok inovasi melalui sistem informasi pemasaran dan media sosial seperti Web Penjualan, Facebook, Path, Instagram Dan Twitter. Kedua pendekatan ini akan dilakukan dengan cara pendekatan kepada petani, berdialog secara langsung kepada petani mengenai permasalahan apa saja yang terjadi, dan menerapkan solusi yang terbaik dengan menerapkan pelatihan dan sistem pemasaran apa yang diperlukan.
\end{abstract}

Kata kunci : Hortikultura, Inovasi, Sistem, dan Pemasaran.

\begin{abstract}
Creating innovation on Horticultural pertaniaan meals are very important to increase the value of sales and marketing it globally is one of the advantages that can be gained in improving the kesehjahteraan farmers Horticulture, with the training and the use of marketing information systems can help the peasants also in creating alternative livelihoods in the currently running. Training innovation activities in village Nagrok hortikuluta food is a form of technology implementation in the Act No. 12 Year 2012 about higher education, so that the villagers can improve the well-being of Nagrok life, innovation do include the training of paste and red bean lunkhead. In addition to Training held needed by the village Nagrok is one medium which helps in marketing the prodok innovation through information systems marketing and social media like Facebook, Web sales, Path, Instagram and Twitter.
\end{abstract}


These two approaches will be carried out by means of approach to the farmer, the farmer directly to dialogue about what problems occurred, and implement the best solution by implementing training and marketing system what required.

Keyword: Horticulture, innovation, systems, and marketing.

\section{A. PENDAHULUAN}

\section{Latar belakang}

Dalam konsep strategi pembangunan dilndonesia menyatakan bahwa sasaran pembangunan jangka panjang, yaitu terciptanya kualitas manusia dan masyarakat Indonesia yang semakin maju dan mandiri dalam rangka pembangunan manusia Indonesia seutuhnya dalam suasana tenteram dan sejahtera lahir batin. ${ }^{1}$

Menurut Kementerian Perdagangan RI definisi ekonomi kreatif disamakan dengan istilah industri kreatif yaitu industri yang berasal dari pemanfaatan kreativitas, keterampilan serta bakat individu untuk menciptakan kesejahteraan dan lapangan pekerjaan dengan menghasilkan dan memberdayakan daya kreasi dan daya cipta individu tersebut. $^{2}$

Sesuai dengan Tujuan dari pemerintah yang tertuang pada undang-undang nomor 12 tahun 2012 tentang pendidikan perguruan tinggiuntuk memberikan membentuk/mengembangkan

sekelompok masyarakat yang mandiri secara ekonomi, membantu menciptakan ketentraman, dan kenyamanan dalam kehidupan bermasyarakat, dan meningkatkan keterampilan berpikir, membaca dan

Uus Ahmad Hunaeni, Potensi Ekonomi Desa Menuju Desa Mandiri (Studi di Desa Sukamanah Kecamatan Karangtengah Kabupaten Cianjur), Journal of Empowerment, Volume. 1, Nomor. 1, Edisi Juni 2017, hlm. 2. Uus Ahmad Hunaeni, (2017), Potensi Ekonomi Desa Menuju ... Ibid, hlm. 8. menulis atau keterampilan lain yang dibutuhka. ${ }^{3}$

Menurut Soemodiningrat, industri kreatif yang mengandalkan talenta, ketrampilan, dan kreativitas merupakan elemen dasar setiap individu. Unsur utama industri kreatif adalah kreativitas, keahlian, dan talenta yang berpotensi meningkatkan kesejahteraan melalui kesejahteraan melalui penawaran kreasi intelektual. ${ }^{4}$

Maka berdasarkan hal tersebut pertanian adalah sektor yang paling penting untuk diterapkan nya iptek, dikarenakan Indonesia adalah negara yang berbentuk kepulauan yang bermata pencaharian sebagai petani. Beraneka ragam makanan pokok banyak dihasiilkan oleh para petani.

Berdasarkan Undang-Undang Republik Indonesia Nomor 13 Tahun 2010 Tentang Hortikultura, bahwa hortikultura dapat dimamfaatkan secara maksimal keberadaannya harus dapat meningkatkan meningkatkan kualitas hidup masyarakat, yang perlu dikelola dan dikembangkan secara efisien dan berkelanjutan. ${ }^{5}$

Maka dari itu sudah seharusnya masyrakat lebih memperhatikan bagaimana menjaga dan memperluas hortikulutra menjadi aset yang harus dilestarikan. Salah satu

Undang-Undang Nomor 12 Tahun 2012 tentang Pendidikan Tinggi

Gunawan Soemodiningrat, (2009), Membangun Perekonomian Rakyat, Yogyakarta, IDEA dan Pustaka Pelajar, hlm. 97.

Undang-Undang Republik Indonesia Nomor 13 Tahun 2010 Tentang Hortikultura. 
bentuk pelestariannya adalah dengan menerapkan bantuan ilmu pengetahuan dan teknologi sehingga dihasilkan sebuah inovasi yang dapat mengembangkan hortikultura sebagai salah satu komoditi nasional Indonesia.

Maka, Petani adalah tokoh utama dalam meningkatkan panganan di Indonesia. Iptek tersebut dapat dikomunikasikan melalui kegiatan pelatihan inovasi panganan, dimana kegiatan ini mempunyai tujuan utama adalah membuat nilai tambah dari hasil pertanian. Kegiatan ini utamanya adalam mengolah bahan pertanian menjadi produk/makanan jadi yang dapat dikonsumsi langsung oleh masyarakat. Inovasi panganan yang dihasilkan membutuhkan ruang lingkup pasar sehingga dibutuhkan suatu sistem yang mendukung pemasaran tersebut dengan adanya sistem pemasaran secara online sebagai media yang membantu dalam memasarkan produk dalam jangkauan luas. Adapun Permasalahan yang teriadi pada masyarakat, yaitu:

a. Belum adanya media atau sarana informasi untuk penduduk Nagrok dalam memiliki pengetahuan produksi, pemasaran dan manajemen yang baik maupun memperluas pendistribusian hasil tani hortikultura;

b. Hanya mengandalkan penjualan hortikultura secara langsung kepada pengepul saja dan tidak adanya media promosi yang digunakan untuk memperluas pangsa pasar Desa Nagrok, dan kurang memperkenalkan bahwa Desa Nagrok adalah salah satu penghasil hortikultura;

c. Tidak adanya suatu kelompok atau organisasi secara khusus untuk membantu masyakarat
Desa Nagrok dalam permasalahan mengenai sektor pertanian khsusuanya bagaimanan mengatur penjualan dan pemasaran hortikultura;

d. Tidak adanya inovasi yang dilakukan dalam memperbaharui hasil panen hortikultura.

Dengan adanya permasalahnya tersebut, maka kegiatan ini dibentuk supaya masyarakat dapat meningkatkan hasil pertanian hortikulturan. Adapun Tujuan Kegiatan adalah:

a. Membangun sistem pemasaran dan manajemen untuk hasil pertanian hortikultura termasuk dari hasil inovasi pengolahan hortikultura;

b. Membangun kelompok binaan yang memberikan bantuan dalam menggunakan sistem pemasaran dan manajemen;

c. Memberikan pelatihan secara khusus mengenai pemasaran dan manajemen keuangan yang baik khususnya untuk para petani hortikultura dalam mengelola keuangan;

d. Memberikan pelatihan bagaiamana membuat makanan ringan dan manisan menggunakan sumber daya hortikultura.

2. Lokasi Pengabdian

Kegiatan ini diadakan didesa Nagrog yang melingkupi dua kelompok yaitu kelompok tani yang berlokasi di Kp. Cikahuripan RT/RW 01/09 Desa Nagrog Kec. Cicalengka dan kelompok wiraswasta yang berlokasi di $\mathrm{Kp}$ Clsepang RT/RW 03/06 Desa Nagrog Kec.Cicalengka. 


\section{Jumlah Peserta}

Jumlah peserta yang mengikuti kegiatan ini masing-masing dari kelompok tani dan wiraswasta adalah 10 orang.

\section{B. METODE}

Didalam melakukan kegiatan pengabdian ini dalam memecahkan permasalahan yang dihadapi menggunakan metode pendekatan deskriptif dan action research sedangkan untuk pembuatan sistem pemasaran menggunkan metode prototype.

\section{HASIL PEMBAHASAN}

Konsep ketahanan pangan menurut Undang-Undang Nomor 7 Tahun 1996 adalah kondisi terpenuhinya pangan bagi rumah tangga yang tercermin dari tersedianya pangan yang cukup, baik jumlah maupun mutunya, aman, merata, dan terjangkau. ${ }^{6}$

Salah satunya yaitu penyuluhan yang akan dilakukan di Desa Nagrok. Desa Nagrog sebuah desa yang berada di kecamatan Cicalengka Kabupaten Bandung Provinsi jawa Barat. yang berlokasi di ketinggian $700 \mathrm{~m}$ diatas permukaan laut mempunyai batasan administratif sebagai berikut:

\begin{tabular}{|c|l|}
\hline Utara & Desa Babakan Peuteuy \\
\hline Selatan & Desa Narawita \\
\hline Barat & Desa Cicalengka Wetan \\
\hline Timur & Desa Citaman \\
\hline
\end{tabular}

Di Desa Nagrog secara bertahap telah dilakukan pembenahan atau penertiban perangkat desa. Desa ini adalah salah satu komoditi tanaman hortikultura Jawa Barat. Perkembangan desa ini pun terlihat dari segi pemerintahannya yang sudah tertata dengan rapih, adanya pembangunan pada sektor-sektor

Uus Ahmad Hunaeni, Potensi Ekonomi Desa ... Op Cit, hlm. 2. pendidikan, lembaga kemasyarakatan. Desa ini selalu aktif dalam kegiatan didalam lembaga kemasyarakatan seperti organisasi Pemuda, Perempuan, Profesi, Bapak dan LKMD. Menjadi salah satu desa yang tingkat ketertiban dan keamanannya minim kejahatan. Dengan luas wilayah 417,162 ha. dengan didominasi penduduk sebagai Petani dan Karyawan Swasta. sebagian kecil berprofesi sebagai Pedagang dan Pegawai Negeri. Berikut data kependudukan dari desa Nagrok:

Tabel 1 Data Kependudukan Desa Nagrok Sumber: Desa Nagrok

\begin{tabular}{|l|l|l|l|}
\hline \multicolumn{4}{|c|}{ Sumber: Desa Nagrok } \\
\cline { 3 - 4 } & & \multicolumn{2}{|c|}{ JUMLAH } \\
\hline 1. & -12 bulan & 213 Orang & 203 Orang \\
\hline 2. & $>1-<5$ Tahun & 798 Orang & 875 Orang \\
\hline 3. & $\geq 5-<7$ Tahun & 345 Orang & 335 Orang \\
\hline 4. & $\geq 7-\leq 15$ Tahun & 1.966 Orang & 1.993 Orang \\
\hline 5. & $>15-56$ Tahun & 6.115 Orang & 6.604 Orang \\
\hline 6. & $>56$ Tahun & 552 Orang & 511 Orang \\
\hline Jumlah & $\mathbf{9 . 9 8 9}$ Orang & $\mathbf{1 0 . 5 2 1}$ Orang \\
\hline
\end{tabular}

Berdasarkan data kependudukan yang ada maka terlihat bahwa setiap tahunnya penduduk desa nagrok selalu bertambah. Hal ini menyatakan bahwa keadaan desa tersebut adalah desa yang produktif. Desa Nagrog sendiri mempunyai mata pencaharian rata-rata sebagai petani dengan budidaya tanaman hortiukultura yang dapat dilihat pada tabel 2 Tanaman Holtikultural Yang Ada Di Desa Nagrog., dengan luas wilayah 417,162 ha. dengan didominasi penduduk sebagai Petani dan Karyawan Swasta. sebagian kecil berprofesi sebagai Pedagang dan Pegawai Negeri Berikut data kependudukan dari desa Nagrok :

Tabel 2 Data Kependudukan Desa Nagrok Sumber: Desa Nagrok

\begin{tabular}{|c|c|c|c|}
\hline \multirow[b]{2}{*}{ NO } & \multirow[b]{2}{*}{ INDIKATOR } & \multicolumn{2}{|c|}{ JUMLAH } \\
\hline & & TAHUN 2009 & TAHUN 2010 \\
\hline 1. & -12 bulan & 213 Orang & 203 Orang \\
\hline 2. & $>1-<5$ Tahun & 798 Orang & 875 Orang \\
\hline 3. & $\geq 5-<7$ Tahun & 345 Orang & 335 Orang \\
\hline 4. & $\geq 7-\leq 15$ Tahun & 1.966 Orang & 1.993 Orang \\
\hline 5. & $>15-56$ Tahun & 6.115 Orang & 6.604 Orang \\
\hline 6. & $>56$ Tahun & 552 Orang & 511 Orang \\
\hline \multicolumn{2}{|c|}{ Jumlah } & 9.989 Orang & 10.521 Orang \\
\hline
\end{tabular}


Berdasarkan data kependudukan yang ada maka terlihat bahwa setiap tahunnya penduduk desa nagrok selalu bertambah. Hal ini menyatakan bahwa keadaan desa tersebut adalah desa yang produktif. Adapun tingkat pendidikan penduduk kelurahan ini adalah seperti tabel 3 berikut :

Tabel 3 Data Tingkat Kependidikan Desa Nagrok Sumber: Desa Nagrok

\begin{tabular}{|c|c|c|c|c|}
\hline \multirow[t]{2}{*}{ NO } & \multirow[t]{2}{*}{ INDIKATOR } & \multirow[t]{2}{*}{ SUB INDIKATOR } & \multicolumn{2}{|c|}{ JUMLAH } \\
\hline & & & TAHUN 2009 & TAHUN 2010 \\
\hline \multirow[t]{8}{*}{1} & \multirow{8}{*}{$\begin{array}{l}\text { Pendidikan Penduduk usia } 15 \\
\text { Tahun ke atas }\end{array}$} & Jumlah penduduk buta huruf & 10 Orang & 10 Orang \\
\hline & & $\begin{array}{l}\text { Jumlah penduduk tidak tamat SD/MI } \\
\text { Sederajat }\end{array}$ & 237 Orang & Orang \\
\hline & & Jumlah penduduk tamat SD/MI Sederajat & Orang & 3.401 \\
\hline & & $\begin{array}{l}\text { Jumlah penduduk tamat SLTP/MTs } \\
\text { Sederajat }\end{array}$ & 1.961 Orang & 2.105 \\
\hline & & $\begin{array}{l}\text { Jumlah penduduk tamat SLTA/MA } \\
\text { Sederajat }\end{array}$ & 1.280 Orang & 1.395 Orang \\
\hline & & Jumlah penduduk tamat D-1 & Orang & Orang \\
\hline & & Jumlah penduduk tamat D-2 & Orang & Orang \\
\hline & & Jumlah penduduk tamat D-3 & 59 Orang & Orang \\
\hline \multirow[t]{3}{*}{2} & \multirow[t]{3}{*}{$\begin{array}{l}\text { Wajib Belajar } 9 \text { tahun dan } \\
\text { putus sekolah }\end{array}$} & Jumlah penduduk tamat SD & $\begin{array}{l}3.224 \\
\text { Orang }\end{array}$ & 3.401 Orang \\
\hline & & $\begin{array}{l}\text { Jumlah penduduk usia 7-15 tahun masih } \\
\text { sekolah }\end{array}$ & 1.969 Orang & 1.993 Orang \\
\hline & & $\begin{array}{l}\text { Jumlah penduduk usia 7-15 tahun putus } \\
\text { sekolah }\end{array}$ & Orang & 76 Orang \\
\hline \multirow[t]{5}{*}{3} & \multirow[t]{5}{*}{ Prasarana Pendidikan } & Jumlah SLTA/MA Sederajat & buah & buah \\
\hline & & Jumlah SLTP/MTs Sederajat & buah & buah \\
\hline & & Jumlah SD/MI Sederajat & buah & 4 buah \\
\hline & & $\begin{array}{l}\text { Lembaga Pendidikan } \\
\text { Agama/Pesantren/RA }\end{array}$ & buah & 10 buah \\
\hline & & $\begin{array}{l}\text { Lembaga Pendidikan } \\
\text { lain(Kursus/sejenisnya) }\end{array}$ & 3 buah & 3 buah \\
\hline
\end{tabular}

Dari tabel di atas dapat dilihat bahwa sebagian besar penduduk Desa Nagrok sudah memiliki tingkat pendidikan yang cukup baik, terlihat dari jumlah penduduk dengan tingkat pendidikan wajib 9 tahun sudah terpenuhi, artinya ini menunjukkan gambaran bahwa desa tersebut memungkinkan untuk menjadi desa yang berkembang dan menjadi desa yang mandiri.

Tabel 4 Data Mata Pencaharian Desa Nagrok Sumber ; Desa Nagrok Tahun 2008

\begin{tabular}{|c|l|r|}
\hline No. & Jenis Mata Pencaharian & Jumlah (orang) \\
\hline 1. & Petani & 70 orang \\
\hline 2. & Buruh Tani & 540 orang \\
\hline 3. & Wiraswasta & 176 orang \\
\hline 4. & PNS & 82 orang \\
\hline 5. & TNI & 30 orang \\
\hline 6. & Pensiunan & 150 orang \\
\hline
\end{tabular}

Berdasarkan dari tabel di atas menyatakan bahwa mata pencaharian terbesar adalah dalam sektor pertanian dan wiraswasta. Dalam hal ini perlu adanya peningkatan dalam sektor ini, dengan tujuan memaksimalkan pengelolaan sektor pertanian dan wiraswasta dengan mengandalkan hasil pertanian hortikulturan serta memberikan peluang usaha baru kepada para penduduk yang tidak memiliki pekerjaan.

\begin{tabular}{|c|c|c|c|c|}
\hline \multirow[b]{2}{*}{ No } & \multirow{2}{*}{$\begin{array}{c}\text { INDI } \\
\text { KAT } \\
\text { OR }\end{array}$} & \multirow{2}{*}{$\begin{array}{c}\text { SUB } \\
\text { INDIKATOR }\end{array}$} & \multicolumn{2}{|c|}{ JUMLAH } \\
\hline & & & $\begin{array}{c}\text { TAHUN } \\
2009 \\
\end{array}$ & $\begin{array}{c}\text { TAHUN } \\
2010 \\
\end{array}$ \\
\hline \multirow{4}{*}{1.} & \multirow[t]{4}{*}{$\begin{array}{l}\text { Peng } \\
\text { angg } \\
\text { uran }\end{array}$} & $\begin{array}{l}\text { 1. Jumlah } \\
\text { penduduk } \\
\text { usia kerja } \\
15-56 \text { tahun }\end{array}$ & 2.201 & $2.332 \mathrm{~g}$ \\
\hline & & $\begin{array}{l}\text { 2. Jumlah } \\
\text { penduduk } \\
\text { usia 15-56 } \\
\text { tahun }\end{array}$ & 6.115 & 6.604 \\
\hline & & $\begin{array}{l}\text { 3. Penduduk } \\
\text { wanita usia } \\
15-56 \text { tahun } \\
\text { menjadi ibu } \\
\text { rumah } \\
\text { tangga }\end{array}$ & $1.392 \mathrm{ng}$ & 1.472 \\
\hline & & $\begin{array}{l}\text { 4. Penduduk } \\
\text { usia > } 15 \\
\text { tahun cacat } \\
\text { sehingga } \\
\text { tidak dapat } \\
\text { bekerja }\end{array}$ & 0 & 0 \\
\hline
\end{tabular}


Dari data inilah, peneliti dapat memberikan kesimpulan adanya permasalahan yang teriadi dengan jumlah penganguran yang cukup tinggi pada tingkatan usia tertentu. Sedangkan kegiatan mata pencaharian hanya berorientasi pada sektor pertanian dan wiraswasta. Dengan adanya hal begitu maka peningkatan pada sektor pertaniaan pun diharapkan harusnya dilakukan untuk meningkatkan pendapatan atau penghasilan pada sector pertanian dan wiraswasta. Maka tentunya ini yang memberikan peluang untuk keterlibatan pemerintah dalam meningkatkan kesejahteraan penduduk Desa Nagrok.

Penduduk desa nagrok mempunyai mata pencaharian sebagai petani dan wiraswasta. Selain itu, Masyarakat Nagrog aktif dalam kegiatan kemasyarakatan dalam pembangunan desa Nagrok, dimana ada beberapa kegiatan yang rutin selalu dilakukan khususnya. Adanya program kerja petani yaitu potensi pengembangan sumber daya unggulan khususnya budidaya hortikultura. Sehingga para petani Desa Nagrok memiliki kesempatan yang luas untuk membangun wirausaha baru dalam sektor pertanian dengan berfokuskan pada inovasi pengolahan hortikultura, dan memperluas pangsa pasar dalam pendistribusian hortikultura, memunculkan badan-badan usaha baru yang menerapkan sebuah sistem pemasaran dan manajeman yang baik khususnya dalam pengelolaan hasil tani hortikultura, memberikan pekerjaan baru kepada para masyarakat yang belum bekerja, menjadi desa mandiri yang dapat menjadi desa percontohan.

Perkebunan adalah segala kegiatan yang mengusahakan tanaman tertentu pada tanah atau tumbuhan lainnya dalam ekosistem yang sesuai, mengolah dan memasarkan barang dan jasa hasil tanaman tersebut, dengan bantuan ilmu pengetahuan dan teknologi, permodalan serta manajemen untuk mewujudkan kesejahteraan bagi pelaku usaha perkebunan dan masyarakat, seperti halnya Hortikultura. ${ }^{7}$

Hortikultura adalah ilmu yang mempelajari budi daya tanaman sayuran, buah-buahan, bungabungaan, dan tanaman hias. Tema buku ini bersifat mendasar bagi mahasiswa pertanian sehingga penulis menyelaraskan antara segi teori dan praktik agar mampu dipahami oleh pembaca. Materi dibahas dari aspek tanaman hortikultura, seperti perkembangan hortikultura; ekologi tanaman hortikultura; pertumbuhan, perkembangan, pembungaan, dan pembuahan pada tanaman hortikultura; panen dan fisiologi lepas panen. 8

Golongan tanaman yang termasuk hortikultura tidak mutlak, secara umum adalah tanaman kebun yang mencakup: Buah; Sayur; Tanaman yang dibudidayakan untuk tujuan keindahan (ornamental), yaitu tanaman hias; Bambu; Tanaman untuk Plantation Crops.

Komoditas hortikultura Pada umumnya ditanam sebagai tanaman sela, tanaman pekarangan, dan kebun. Seiring dengan nilai komersialnya yang tinggi, terutama sayuran dan tanaman hias, banyak

Bustanul Arifin, (2004), Analisis Ekonomi Pertanian Indonesia, Jakarta, Kompas, hlm. 27. Zulkarnain, (2010), Dasar-dasar hortikultura, Jakarta, Bumi Aksara, Tanpa Halaman. 
dikembangkan melalui budidaya hidroponik. ${ }^{9}$

Kegunaan hortkultura sendiri sebagai berikut:

1. Sebagai sumber karbohidrat, protein, lemak, dan serat;

2. Sebagai sumber vitamin, mineral, enzim, hormon, anti oksidan, dan berbagai bahan aktif obat alami yang bermanfaat bagi kesehatan dan kebugaran;

3. Memperbaiki dan melestarikan fungsi lingkungan;

4. Sebagai komponen penting dalam berbagai kegiatan upacara; dan

5. Sebagai bagian dari peningkatan nilai estetika.

Berdasarkan pengertian dan masalah yang sedang dihadapi maka Desa Nagrok membutuhkan suatu pelatihan yang dapat membantu dan mendukung dalam memperluas dan mengembangkan hortikultura.

Menurut Ike Kusdyah Rachmawati Pelatihan merupakan wadah lingkungan bagi karyawan dimana mereka mempelajari sikap, kemampuan, keahlian, pengetahuan dan perilaku spesifik yang berkaitan dengan pekerjaan. Seringkali terjadi pada karyawan baru bahwa kemampuan dan keterampilan yang mereka miliki belum sesuai dengan yang diharapkan organisasi sehingga biasanya organisasi harus selalu melakukan program pelatihan untuk karyawan. Pelatihan tidak hanya dilakukan pada karyawan baru saja tetapi karyawan lamapun kemampuan dan keahliannya perlu diupgrade untuk memberikan

Ambarwati, Erlina, (2012), Pendahuluan: Pengertian Agronomi Dan Hortikultura Beserta Ruang Lingkupnya. Bahan Ajar Mata Kuliah Dasar-Dasar Agronomi D, Fakultas Pertanian, UGM, Yogyakarta penyegaran serta menyesuaikan tuntutan pekerjaan yang berubah. ${ }^{10}$

Kegunaan dari pelatihan bagi masyarakat desa Nagrok antara lain:

1. Mendorong pencapaian pengembangan diri masyarakat petani Desa Nagrok;

2. Memberikan kesempatan bagi para petani untuk berkembang dan memiliki pandangan tentang masa depan kariernya;

3. Membantu petani dalam menangani konflik dan ketegangan;

4. Meningkatkan kepuasan kerja dan prestasi kerja;

5. Menjadi jalan untuk perbaikan keterampilan dalam bersosialisasi dan berkomunikasi;

6. Membantu menghilangkan ketakutan dalam mencoba halhal baru dalam pekerjaan;

7. Menggerakkan petani untuk mencapai tujuan-tujuan organisasi.

Sehingga akan banyak keuntungan yang diperoleh oleh para petani desa Nagrok dengan diadakannya kegiatan inovasi pelatihan ini seperti:

1. Dapat mendidik para petani untuk bekerja lebih trampil, cepat dan efektif;

2. Dapat mengurangi kesalahankesalahan dalam bekerja;

3. Dapat memberikan atau meningkatkan pengetahuan dan ketrampilan pegawai;

4. Dapat meningkatkan percaya diri, tanggung jawab dan harga diri yang berpengaruh terhadap semangat keria para petani;

5. Dapat menciptakan dan mengembangkan metode kerja yang lebih baik dalam

10 Ike Kusdyah Rachmawati, (2008), Manajemen Sumber Daya Manusia, Andi Offset, Yogyakarta. 
6. mengembangkan hasil pertanian hortikultura. ${ }^{11}$

Salah satu komoditi yang dihasilkan oleh desa Nagrog adalah Kacang merah berdasarkan data yang diperoleh dapat dilihat dalam tabel 1 tanaman hortikulturan Desa Nagrog

\begin{tabular}{|c|l|c|c|c|l|}
\hline No & $\begin{array}{c}\text { Nama } \\
\text { Tanaman }\end{array}$ & $\begin{array}{c}\text { Luas } \\
\text { Lahan/ } \\
\text { Popula } \\
\mathbf{s i} / \mathbf{H a}\end{array}$ & $\begin{array}{c}\text { Produk } \\
\text { tifitas/ } \\
\text { Ha }\end{array}$ & $\begin{array}{c}\text { Jumlah } \\
\text { Rumah } \\
\text { Tangga }\end{array}$ & $\begin{array}{c}\text { Catatan } \\
\text { Panen }\end{array}$ \\
\hline 1 & Cabe & 5 & 0,8 & 70 & $3 /$ tahun \\
\hline 2 & Tomat & 5 & 8 & 35 & $2 /$ tahun \\
\hline 3 & $\begin{array}{l}\text { Kacang } \\
\text { Merah }\end{array}$ & 65 & 1,2 & 227 & $2 /$ tahun \\
\hline 4 & $\begin{array}{l}\text { Pisang } \\
\text { Gronis }\end{array}$ & 1 & $\begin{array}{c}\text { Masih } \\
\text { Tanam }\end{array}$ & - & $3 /$ tahun \\
\hline 5 & Sawo & 2,5 & 2 & - & $1 /$ tahun \\
\hline 6 & Alpukat & 2 & 1 & - & $1 /$ tahun \\
\hline 7 & $\begin{array}{l}\text { Mangga } \\
\text { Aromanis }\end{array}$ & 1 & 0,6 & - & $1 /$ tahun \\
\hline 8 & Durian & 1 & 0,5 & - & $1 /$ tahun \\
\hline
\end{tabular}

Analisa sebelumnya dengan judul Model Pertanian Terpadu Tanaman Hortikultura dan Ternak Sapi untuk Meningkatkan Pendapatan Petani, dimana tujuannya adalah memberikan satu inovasi baru bahwa dengan limbah hortikultura dapat dijadikan pangan ternak sapi sehingga para petani dapat membuat satu alternatif solusi untuk meningkatkan pendapatan para petani Kegiatan ini membuktikan bahwa tanaman hortikulura memberikan multifungsi kepada para petani dengan memaksimalkan pengelolaan tanaman hortikultura. ${ }^{12}$

Dengan mengutamakan tanaman hortikultura sebagai sumber hasil

11 Dartha Ketut I, Pengaruh Pendidikan Dan Pelatihan (Diklat) Terhadap Kinerja Pegawai Negeri Sipil Pada Sekretariat Daerah Kota Malang, Jurnal Ekonomi Modernisasi Fakultas Ekonomi Universitas Kanjuruhan Malang Volume 6, Nomor 2, Edisi Juni 2010, hlm. 105-110

12 Pandi Pardian, Strategi Pengembangan Usaha Oncom terhadap tenaga kerja pedesaan guna penguatan ketahanan pangan dan kesejahteraan Masyarakat, Jurnal Sosiohumanior, Volume. 14, Nomor. 1, Edisi Maret 2012, hlm. 105-115. bagi para petani maka inovasi tidak hanya dilakukan pada saat tanaman hortikulutra menjadi limbah/sampah tetapi memberikan satu keunggulan lain dengan tanaman hortikultura yaitu dengan membuat panganan yang diolah dari tanaman hortikultura.

Untuk desa nagrok banyak tanaman yang dihasilkan yang dapat dijadikan panganan khas daerah nagrok sendiri seperti pisang dapat dijadikan aneka keripik pisang, tomat dapat dijadikan aneka manisan, kacang merah dapat dijadikan pasta dan dodol kacang merah.

Kelebihan dari kegiatan pengabdian ini dibandingkan dengan yang lainnya adalah:

1. Aneka ragam dari inovasi yang diberikan kepada masyarakat menjadi pengetahuan para petani dalam meningkatkan pendapatan sehari-hari;

2. Dengan sistem pemasaran yang diberikan mampu memperluas jangkauan pangsa pasar yang ada.

Kelemahaannya adalah Para petani mungkin akan kurang memahami mengenai sistem informasi pemasaran yang dilakukan dikarenakan keterbatasan pengetahuan dan alat pendukung yang dibutuhkan dalam pemasaran.

Menurut William J. Santon dalam Swastha dan Irawan, mengatakan bahwa pemasaran adalah suatu sistem keselururuhan dari kegiatankegiatan bisnis yang ditujukan untuk merencanakan, menentukan harga, mempromosikan, dan mendistribusikan barang dan jasa yang memuaskan kebutuhan, baik 
kepada pembeli yang ada maupun pembeli potensial. ${ }^{13}$

Menurut The American Marketing Association (AMA), pemasaran merupakan organisasional dan penciptaan satu set preoses-proses, komunikasi, dan mengirimkan nilai pada konsumen-konsumen, dan untuk mengatur relasi pada konsumen yang bertujuan untuk keuntungan pihakpihak yang bersangkutan. ${ }^{14}$

Sedangkan menurut Rangkuti, Pemasaran adalah suatu proses kegiatan yang dipengaruhi oleh berbagai faktor, seperti :

1. Sosial;

2. Budaya;

3. Politik;

4. Ekonomi; dan

5. Manajerial.

Dengan begitu maka begitu pentingnya kegiatan inovasi panganan hortikultura bagi masyarakat Desa Nagrok. Adapun kegiatan pelatihan ini meliputi pelatihan pembuatan pasta dan dodol kacang merah serta pembuatan sistem informasi pemasaran bagi hasil dari inovasi panganan hortikultura yang diterapkan untuk meningkatkan pemasaran, promosi, tetapi tidak menghilangkan ciri khas dan kearifan lokal masyarakat desa Nagrog.

Menurut Mardikanto dan Soebianto, dalam proses perubahan memerlukan inovasi berupa ide, produk, metode, peralatan, dan teknologi dengan kajian serta pengembangan kebiasaan, nilai, tradisi pada kearifan lokal (indigenous

13 Mega Ratri Ayu Aksani, (2017), Analisis Strategi Dan Manajeman Ekspor Produk Hortikultura Di Pt. Bumi Sari Lestari Temanggung, Doctoral Dissertation, Universitas Muhammadiyah Semarang, hlm. 8.

14 Mega Ratri Ayu Aksani, (2017), Analisis ... Ibid, hlm. 8 . technology). Proses untuk memfasilitasi dan mendorong masyarakat menjadi pelaku utama dalam memanfaatkan lingkungan untuk mencapai keberlanjutan (sustainable development) jangka panjang. ${ }^{15}$

Demi terlaksananya inovasi yang ideal maka perlu adanya konsep pemasaran yang, seperti halnya menurut Kotler dan Keller terdapat 5 (lima) konsep pemasaran, yaitu :

1. Konsep produksi;

2. Konsep produk;

3. Konsep penjualan;

4. Konsep pemasaran falsafah; dan

5. Konsep pemasaran sosial. ${ }^{16}$

Selain itu perlu suatu manajemen pemasaran yang mengatur dan mengarahkan suatu pemasaran sesuai dengan konsep yang di buat.

Manajemen pemasaran itu sendiri dibagi menjadi 2 (dua) kata, yaitu manajemen dan pemasaran. Menurut Kotler dan Armstrong pemasaran adalah analisis, perencanaan, implementasi, dan pengendalian dari program-program yang dirancangkan untuk menciptakan, membangun, dan pertukaran yang menguntungkan dengan pembeli sasaran untuk mencapai tujuan perushaan. Sedangkan manajemen adalah preses perencanaan pengorganisasian, pergerakan, dan pengawasan. ${ }^{17}$

15 Adhi Iman Sulaiman, Bambang Kuncoro, Endang Dwi Sulistyoningsih, Hikmah Nuraeni, Fatmah Siti Djawahir, Strategi Pengembangan Komoditi Pertanian Unggulan Di Kabupaten Ponorogo, AGRISTA-Jurnal Imiah Mahasiswa Agribisnis Volume. 3, Nomor. 3, 2015, hlm. 19

16 Mega Ratri Ayu Aksani, (2017), Analisis ... OP Cit, hlm. 9

17 Mega Ratri Ayu Aksani, (2017), Analisis ... Ibid, hlm. 9-10. 
Maka manajemen pemasaran dapat diartikan sebagai analisis, perencanaan, penerapan dan pengendalian program yang dirancang untuk menciptakan, membangun, dan mempertahankan pertukaran yang menguntungkan dengan pasar sasaran dengan maksud untuk mencapai tujuan-tujuan organisasi. ${ }^{18}$

Dalam organisasi, baik organisasi non-laba maupun perusahaan, yang mempunyai beberapa jenjang manajerial, peran pemasaran untuk masing-masing jenjang pasti berbeda. ${ }^{19}$ Sebuah perusahaan yang besar misalnya, mempunyai tiga jenjang manajerial, yaitu manajemen puncak, manajemen madya, dan manajemen operasional. Jika dilihat pada jenjang organisasionalnya, jenjang paling atas disebut jenjang korporat, jenjang menengah disebut jenjang unit bisnis strategik, dan jenjang paling bawah disebut jenjang operasional. Pemasaran dibutuhkan oleh setiap jenjang dalam perusahaan dengan peran yang berbeda seperti dikemukakan oleh Webster, Jr. ${ }^{20}$

Konsep Pemasaran sebagai filosofi bertujuan memberikan kepuasan pada keinginan dan kebutuhan pelanggan atau konsumen. Seluruh kegiatan dalam perusahaan yang menganut konsep pemasaran harus diarahkan untuk memenuhi tujuan tersebut. Kegiatan ini meliputi kegiatan pada semua bagian yang ada, seperti kegiatan personalia, produksi, keuangan, riset dan pengembangan, serta fungsi-fungsi

18 Mega Ratri Ayu Aksani, (2017), Analisis ... Ibid, hlm. 10.

19 Basu Swastha Dharmmesta, (2014), Manajemen Pemasaran, Modul, Universitas Terbuka, Tanggerang Selatan hlm. 9.

20 Basu Swastha Dharmmesta, (2014), Manajemen ... Ibid, hlm. 9. lainnya. Meskipun orientasi pelanggan dibatasi oleh tujuan laba dan pertumbuhan, tetapi filosofi tersebut perlu dilaksanakan. ${ }^{21}$

Hal ini dimaksudkan untuk mengantisipasi dampak yang muncul, yaitu pada peningkatan penjualan, misalnya dengan cara :

1. Membuat barang yang mudah penggunaannya;

2. Mudah pembeliannya; dan

3. Mudah pemeliharaannya. ${ }^{22}$

Penerapan Konsep Pemasaran ini sangat potensial terutama untuk perusahaan-perusahaan yang beroperasi tanpa menggunakan pedoman yang berprinsip pada pemuasan pelanggan.

Maka daripada itu kegiatan pemasaran dan pelatihan inovasi panganan hortikultura ini didasarkan kepada Pendeketan dengan metode deskriptif dan analisis. Adapun tahapan yang dilakukan adalah sebagai berikut:

1. Konfirmasi ruangan untuk pelaksanaan pelatihan;

2. Tujuannya adalah ketika kegiatan pelatihan dilaksanakan maka ada tempat/ruang sehingga kegiatan dapat dilakukan secara maksimal. Ruangan yang digunakan minimal dapat menampung sebanyak 20 orang, berdasarkan jumlah peserta dilibatkan kedalam penelitian ;

3. Penyepakatan jadwal kegiatan dengan para petani Desa Nagrok. Tujuannya agar para petani dapat mengikuti seluruh rangkaian acara kegiatan yang sudah disepakati bersama, sehingga para petani dapat

\footnotetext{
Basu Swastha Dharmmesta, (2014), Manajemen ... Ibid, hlm. 11.

22 Basu Swastha Dharmmesta, (2014), Manajemen ... Ibid, hlm. 11-12.
} 
menerima materi pelatihan secara keseluruhan;

4. Mempersiapkan instruktur pelatihan. Tujuannya adalah menyediakan narasumber yang merupakan pakar dari inovasi pelatihan tersebut, sehingga pelatihan dapat dilaksankan secara maksimal;

5. Penyepakatan kembali pembagian tugas Tim Pengabdian kepada Masyarakat Unikom. Tujuannya adalah supaya kegiatan pengabdian berjalan dengan lancar dikarenakan pembagian tugas diberikan diawal sehingga para anggota pengabdian dapat melakukan tugasnya masing-masing;

6. Penjelasan tugas kepada personil para petani yang terlibat langsung dalam kegiatan pelatihan. Tujuannya menjelaskkan agar para petani bisa terlibat sebagai peserta dengan aturan-aturan yang sudah disepakati bersama;

7. Memastikan tempat pemesanan makanan dan snack untuk peserta, instruktur, dan tim pelaksana. Berjalannya kegiatan pengabdian ini pun, dilakukan persiapan-persiapan yang dilakukan untuk mendukung acara kegiatan pengabdian ini;

8. Mempersiapkan ruangan untuk pelatihan. Sebelum kegiatan pelatihan dilaksankan dipastikan ruangan sudah dipersiapkan sehingga pada saat pelaksanaan bisa berjalan dengan waktu yang sudah ditentukan;

9. Penggandaan modul pelatihan. Selain narasumber yang disediakan maka kegiatan pelatihan ini menyiapkan modul pelatihan sehingga membantu dan mempermudah peserta dalam mengikuti kegiatan pelatihan;

10. Menyiapkan alat peraga. Alat peraga yang disiapkan meliputi alat-alat masak yang dibutuhkan dalam pelatihan pembuatan pasta dan dodol kacang merah. Alat peraga ini dipersiapkan sebelum kegiatan pelatihan ini dilaksanakan.

Kegiatan Inovasi Pelatihan Panganan Hortikultura dalam kegiatan pelatihan kepada masyarakat ada dua kegiatan yang dilakukan, yaitu: 23

1. Pembuatan pasta kacang merah

a. Cuci bersih kacang merah, kemudian rendam semalaman atau hingga 24 jam dengan mengganti air 3-4 kali;

b. Masukkan kedalam panci presto, beri air hingga kacang merah terendam, kemudian masak dengan panci presto selama 45 menit atau hingga kacang merah lunak;

c. Tiriskan, kemudian blender atau haluskan kacang merah hingga lembut, lalu masak kembali menggunakan wajan. Lalu campurkan dengan gula dan garam, masak dengan api kecil hingga kental dan padat;

d. Dinginkan, dan pasta kacang merah siap digunakan.

2. Pembuatan Dodol Kacang Merah

a. Lakukan proses nomor 1, 2, dan 3 pada pembuatan pasta kacang merah, atau gunakan hasil pembuatan pasta kacang merah;

b. Masak diatas panci dengan api kecil, campurkan dengan kelapa

23 Peraturan Pemerintah Nomor 28 Tahun 2004 Tentang Keamanan, Mutu dan Gizi Pangan 
parut, gula, dan tepung ketan. Masak hingga kalis; dan

c. Padat bungkus menggunakan kertas minyak. Dodol kacang merah siap disajikan.

3. Hasil Kegiatan

a. Kegiatan ini diawali dengan mempersiapkan bahan kacang merah yang akan diolah. Membersihkan dan menghaluskan kacang merah menggunakan blender;

b. Setelah menghaluskan kacang merah, maka para petani melakukan kegiatan pemanasan atau pemanggang kedalam wajan besar dan sambil mengaduk-ngaduk kacang merah;

c. Kegiatan ini adalah kegiatan dimana pasta dan dodol kacang merah sudah jadi dan kemudian diberikan pengemasan. Untuk pengemasan bisa dilakukan dalam wadah yang berbeda seperti kertas wajit dan laiinya.

Sistem informasi pemasaran adalah suatu struktur yang berlanjut dan saling berkait dari orang, peralatan, dan prosedur yang ditunjukkan untuk mengumulkan, menyaring, menganalisa, dan membagikan informasi yang spesifik, tepat waktu, dan cermat untuk digunakan oleh para pengambil keputusan di bidang pemasaran dan tujuan penyempurnaan perencanaan, pelaksanaan dan pengendalian pemasaran. ${ }^{24}$

Menurut Mukaromah dan Sari adanya media baru yang dapat digunakan oleh pekerja humas (public relations officer), untuk melaksanakan fungsinya dalam berkomunikasi dan

Kotler, Philip, (2009), Manajemen Pemasaran, Jilid 1, Jakarta, Erlangga, Tanpa Halaman. memberikan informasi kepada stakeholder. ${ }^{25}$

Adapun komponen dari sistem informasi pemasaran sebagai berikut:

1. Komponen Input Pemasaran

Sistem informasi pemasaran
mengumpulkan data yang
menjelaskan transaksi
pemasaran perusahaan.
Subsistem intelejen pemasaran
mengumpulkan informasi dari
lingkungan perusahaan yang
berkaitan dengan operasi
pemasaran. Subsistem peneliti
pemasaran menlakukan
penelitian khusus mengenai
operasi pemasaran.

2. Komponen Model Pemasaran Model digunakan untuk menghasilkan informasi yang relevan yang sesuai dengan kebutuhan pemakai sistemnya. Model merupakan cetakan yang merubah bentuk input menjadi output. Model di sistem informasi pemasaran banyak digunakan untuk menghasilkan laporan keperluan anggaran operasi, strategi penentuan harga produk, evaluasi produk baru, pemilihan lokasi fasilitas, evaluasi penghapusan produk lama,penunjukan salesman, penentuan rute pengiriman yang paling optimal, pemilihan media iklan yang paling efektif dan untuk persetujuan kredit.

3. Komponen Basis Data Pemasaran

\footnotetext{
25 Mukaromah, dan Sari, D.V. Laman dan Reputasi Lembaga dalam Membangun Komunikasi dengan Stakeholders. The Messenger. Volume. 8, Nomor. 2, 2016, hlm. 35 42 .
} 
Data yang digunakan oleh Subsistem out put berasal dari data base. Beberapa data dalam data base adalah unik bagi fungsi pemasaran, tapi banyak Yang berbagi dengan area fungsional lain.

\section{Komponen Output Pemasaran}

Tiap Subsistem out put menyediakan informasi tentang Subsistem itu sebagai bagian dari bauran Subsistem produk menyediakan informasi tentang produk perusahaan. Subsistem promosi menyediakan informasi tentang kegiatan periklana perusahaan dan penjualan langsung. Subsistem harga membantu manajer untuk membuat keputusan harga.

Kegiatan ini mempunyai beberapa proses tahapan anlisis dan kewirausahaan dimana masingmasing kegiatan terdiri dari beberapa kegiatan yang dilakukan. Tahapan analisis dan kewirausahaan, yaitu Proses pertama, tahapan analisi dalam pembuatan sistem pemasaran:

1. Menentukan arah dan capaian dalam pembuatan sistem pemasaran;

2. Menentukan indentifkasi masalah;

3. Indentifikasi proses kegiatan petani;

4. Pengumpulan data kebutuhan.

Maka kedua tahapan ini akan dihasilkan simulasi sistem pemasaran dan pelatihan inovasi olahan panganan hasil pertanian. Pembuatan sistem pemasaran yang dilaksanakan meliputi beberapa kegiatan yang dilakukan. Secara garis besar, solusi yang ditawarkan adalah kerjasama antara Tim Pengabdian kepada Masyarakat Unikom dengan Desa Nagrok untuk membuatkan sistem pemasaran dan melakukan pelatihan bagi masyarakat Desa Nagrok yang memenuhi kriteria. Beberapa pendekatan yang digunakan untuk efektifitas hasil pelatihan adalah:

1. Pengumpulan Data

Dilaksanakan dalam waktu 1 minggu dengan ketentuan 6 jam untuk hari ditentukan berdasarkan waktu para petani bersifat fleksibel. Dilakukan oleh ketua peneliti untuk wawancara kepada para petani, serta anggota kedua sesuai dengan bidang keahlian agrobisnis.

2. Pembuatan Sistem

Dilaksanakan Selama 6 bulan terakhir dilakukan dari awal pertama melakukan penelitian. Tugas ini dilakukan oleh anggota Peneliti 1 sebagai anggota analysis system dan pembuatan software.

3. Pelatihan

Terdiri dari pelatihan sistem pemasaran dan sistem manajemen pemasaran dan manajemen kevangan, dari pelatihan tersebut dilakukan selama 3 bulan terakhir sebelum penyusunan laporan akhir. Pelatihan ini akan diadakan setiap hari sabtu dan minggu dari pukul 08.00-12.00. Kegiatan ini akan menghadirkan staf ahli dari pemasaran dan kevangan, dan anggota peneliti 2 dibantu oleh para mahasiswa.

4. Seminar

Kegiatan ini dimaksudkan untuk mejelaskan sistem secara keseluruhan dari awal fungsi penjelasan sistem pemasaran, kemudian pelatihan manajemen 


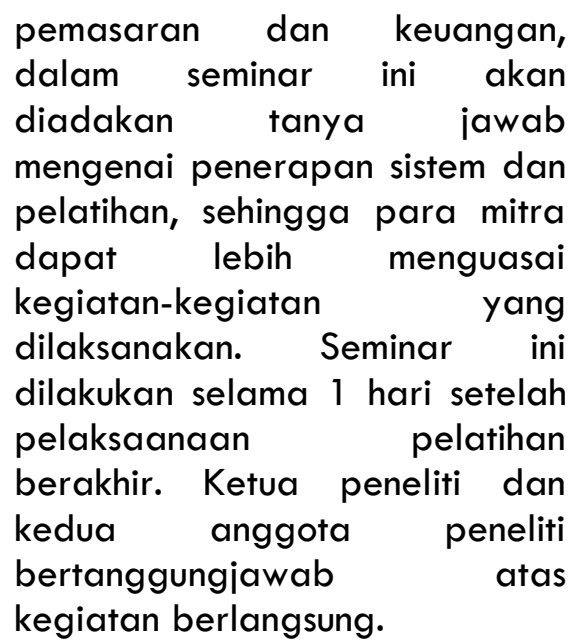

5. Penyusunan Laporan

Kegiatan terakhir yang dilakukan setelah proses kegiatan sosialisasi, pelatihan dan kegiatan seminar berakhir. Setiap bagian sesuai dengan bidang keahliannya masingmasing menyerahkan laporan pertanggungjawaban kepada ketua peneliti. Dan ketua peneliti menyelesaikan laporan akhir secara keseluruhan.

6. Pelatihan sistem pemasaran melalui media sosial.

a. Facebook

Menurut Priyanto facebook adalah website jaringan sosial dimana

para pengguna dapat bergabung dalam komunitas seperti Kota, kerja, dan daerah untuk melakukan koneksi berinteraksi dengan orang lain. 26

Maka dari itu salah satu media ini sangat menguntungkan jika digunakan dengan tepat. Masyarakat pada saat ini lebih

26 Hari Priyanto, (2009), Sukses di Era Facebook, Kiat-kiat Memanfaatkan Media Sosial Untuk Kemenangan Gemilang, Bandung, PT How Prees, Tanpa Halaman. mudah dan lebih menyukai media facebook sebagai sarana hiburan bagi mereka untuk berkenalan, temu sapa dan lainnya. Dengan adanya hal ini, maka para petani bisa memamfaatkan media ini sebagai salah satu komunikasi yang menjadi penghubung dalam memperkenalkan produk hortikultura dalam bentuk inovasi panganan.

b. Twitter

Penggunaan media sosial twittersebagai sarana komunikasi bagi masyarakat memiliki kekuatan tersendiri dibanding dengan media sosial lainnya, yaitu media sosial twitter memiliki kapasitas dalam melakukan update status atau biasa disebut dengan tweet hanya berjumlah 140 karakter. Selain itu, penggunaan status dalam media sosial twitter yang berjumlah 140 karakter ini lebih disukai oleh masyarakat karena dinilai lebih mudah dan praktis. Meskipun hanya memiliki kapasitas 140 karakter dalam melakukan update status, namun penggunaan media sosial twitter sampe pada saat ini dinilai mampu dalam mengirimkan pesan yang ingin disampaikan. 27

Media sosial ini pun dalam masyarakat menjadi salah satu media yang paling mudah untuk digunakan maka para petani dapat memamfaatkan media ini

27 Novia Ika Setyani, Penggunaan Media Sosial Sebagai Sarana Komunikasi Bagi Komunitas (Studi Deskriptif Kualitatif Penggunaan Media Sosial Twitter, Facebook, dan Blog sebagai Sarana Komunikasi bagi Komunitas Akademi Berbagi Surakarta), Jurnal Komunikasi, Volume 13, Nomor. 7, 2013, hlm. 103-108. 
sebagai salah satu media pemasaran.

c. Path

Path ini dimotori oleh Dave

Morin, Shawn Fanning, dan Dustin Mierau, dan perusahaan ini berlokasi di San Fransisco, USA. 28 Path digunakan untuk berbagi foto dan pesan kepada para pengguna lainnya. Perbedaan dengan aplikasi media sosial lainnya, yaitu kemungkinan mengakses profile antar pengguna Path ketika antara dua belah pihak sudah saling berteman atau disetujui oleh akun Path penggunanya.

Sehingga privasi masih dapat terjaga. Beberapa fitur yang dimiliki Path, antara lain dapat membuat profile-nya sendiri, pengunggahan foto maupun video, lokasi dimana pengguna saat itu berada, meng-update status serta komentar, berbagi film, musik, serta buku kepada pengguna lainnya. Path juga menyediakan tombol tidur, di mana ketika tombol tersebut diaktifkan, maka pengguna tidak dapat mengakses halamannya, dan yang terakhir adalah kemudahan para penggunanya untuk saling mengirimkan pesan kepada pengguna Path lainnya.

Media path ini bisa digunakan dalam teknik pemasaran dalam mempromosikan inovasi panganan hortikulturan karena menyediakan banyak beberapa fasilitas seperti foto, video dan audia lainnya. Sehingga menjadi

28 Priguna, S. (2012). Path, Jejaring Sosial Baru yang Menyenangkan Chip. Diakses dari:http: / / chip.co.id/news/general/2690/ path_jejaring_sosial_baru_yang_menyenangk an pada 21 Oktober 2017 salah satu kemudahan bagi para petani Desa Nagrok.

d. Instagram

Instagram merupakan salah satu fitur yang dimiliki oleh smartphone atau telepon pintar. 29 Instagram merupakan aplikasi handphone yang berbasis Android, selain itu Instagram juga merupakan aplikasi yang digunakan untuk menjepret foto, mengelola foto, mengedit foto, memberi efek filter pada foto dan membagikan foto tersebut kesemua orang.

e. Sistem informasi pemasaran berbasis web.

Web merupakan aplikasi jaringan yang mendukung terlaksananya HTTP (Hyper Text Tansfer Protokol) dalam suatu jaringan internet. Internet merujuk kepada infrastruktur jaringan,sedangkan web merujuk kepada salah satu aplikasi yang berjalan dalam jaringan internet. Pengguna web sebagai media penyampaian mengenai sistem informasi data spesial yang dibutuhkan tanpa harus mendatangi tempat penyedia data tersebut.

Selain Media Pemasaran Maka untuk membantu Desa Nagrok dalam melakukan penjualan dan pembelian dibuatkan sebuah sistem informasi untuk memfasilitasi layanan tersebut kepada masyarakat.
29 Agustina, Analisis Penggunaan Media Sosial Instagram Terhadap Sikap Konsumerisme Remaja Di SMA Negeri 3 Samarinda”, EJournal Ilmu Komunikasi, Volume. 4, Nomor. 3, 2016, hlm. 402-412. 


\section{PENUTUP}

\section{Kesimpulan}

Dengan adanya kegiatan pelatihan dan penyuluhan ini dapat memberikan beberapa hal yang penting yaitu:

a. Bahwa Desa Nagrok berpotensi untuk menjadi desa yang berkembang dikarenakan termasuk wilayah strategis untuk tanaman hortikultura.

b. Desa Nagrok memiliki sumber daya manusia yang potensial untuk melakukan inovasi panganan yang diberikan.

c. Para petani Desa Nagrok kini sadar bahwa betapa pentingnya sistem pemasaran yang dibutuhkan untuk inovasi panganan yang dilakukan.

d. Para petani desa nagrok sudah mengetahui bahwa pemasaran dapat dilakukan dengan menggunakan media sosial.

\section{Saran}

a. Harus diadakan pembentukan Usaha Kecil Menengah Bagi para petani desa Nagrok sebagai wadah melakukan kegiatan inovasi panganan dan pemasaran.

b. Adanya Wadah yaitu sistem informasi pemasaran dalam melakukan pemasaran inovasi panganan.

c. Adanya teknik pengemasan yang dilakukan oleh petani dalam memberikan nilai tambah pada hasil olahan inovasi hortikultura

\section{UCAPAN TERIMAKASIH}

Mengucapkan rasa terimakasih sebesar-besarnya Kepada DIPA Direktorat Penelitian dan Pengabdian kepada Masyarakat Kementerian Pendidikan dan Kebudayaan sesuai dengan Surat
Perianjian Penugasan Pelaksanaan Program Pengabdian Kepada Masyarakat Direktorat Riset Dan Pengabdian Kepada Masyarakat Tahun Anggaran 2017 Nomor 64/SP/LPPM/UNIKOM/VI/2017 yang sudah berkenan memberikan dana untuk kegiatan pengabdian ini.

\section{DAFTAR PUSTAKA}

\section{A. Buku}

Bustanul Arifin, (2004), Analisis Ekonomi Pertanian Indonesia, Jakarta, Kompas.

Gunawan Soemodiningrat, (2009), Membangun Perekonomian Rakyat, Yogyakarta, IDEA dan Pustaka Pelajar.

Hari Priyanto, (2009), Sukses di Era Facebook, Kiat-kiat Memanfaatkan Media Sosial Untuk Kemenangan Gemilang, Bandung, PT How Prees.

Ike Kusdyah Rachmawati, (2008), Manajemen Sumber Daya Manusia, Yogyakarta, Andi Offset.

Kotler, Philip, (2009), Manajemen Pemasaran, Jilid 1, Jakarta, Erlangga.

Zulkarnain, (2010), Dasar-dasar hortikultura, Jakarta, Bumi Aksara.

\section{B. Peraturan Undangan}

Perundang-

Undang-Undang Republik Indonesia Nomor 13 Tahun 2010 Tentang Hortikultura. 
Peraturan Pemerintah Nomor 28 Tahun 2004 Tentang Keamanan, Mutu dan Gizi Pangan.

\section{Jurnal}

Adhi Iman Sulaiman, Bambang Kuncoro, Endang Dwi Sulistyoningsih, Hikmah Nuraeni, Fatmah Siti Djawahir, Strategi Pengembangan Komoditi Pertanian Unggulan Di Kabupaten Ponorogo, AGRISTAJurnal Imiah Mahasiswa Agribisnis Volume. 3, Nomor. 3, 2015.

Agustina, Analisis Penggunaan Media Sosial Instagram Terhadap Sikap Konsumerisme Remaja Di SMA Negeri 3 Samarinda, E-Journal Ilmu Komunikasi, Volume. 4, Nomor. 3, 2016.

Dartha Ketut I, Pengaruh Pendidikan Dan Pelatihan (Diklat) Terhadap Kineria Pegawai Negeri Sipil Pada Sekretariat Daerah Kota Malang, Jurnal Ekonomi Modernisasi Fakultas Ekonomi Universitas Kanjuruhan Malang Volume 6, Nomor 2, Edisi Juni 2010.

Novia Ika Setyani, Penggunaan Media Sosial Sebagai Sarana Komunikasi Bagi Komunitas (Studi Deskriptif Kualitatif Penggunaan Media Sosial Twitter, Facebook, dan Blog sebagai Sarana Komunikasi bagi Komunitas Akademi Berbagi Surakarta), Jurnal Komunikasi, Volume. 13, Nomor. 7, 2013.

Mukaromah, dan Sari, D.V. Laman dan Reputasi Lembaga dalam Membangun Komunikasi dengan
Stakeholders. The Messenger. Volume. 8, Nomor. 2, 2016.

Pandi Pardian, Strategi Pengembangan Usaha Oncom terhadap tenaga kerja pedesaan guna penguatan ketahanan pangan dan kesejahteraan Masyarakat, Jurnal Sosiohumanior, Volume. 14, Nomor. 1, Edisi Maret 2012.

Uus Ahmad Hunaeni, Potensi Ekonomi Desa Menuju Desa Mandiri (Studi di Desa Sukamanah Kecamatan Karangtengah Kabupaten Cianjur), Journal of Empowerment, Voumel. 1, Nomor. 1, Edisi Juni 2017.

D. Makalah, Diktat, Modul, Skripsi, Tesis, atau Disertasi dan Lain-lain

Basu Swastha Dharmmesta, (2014), Manajemen Pemasaran, Modul, Universitas Terbuka, Tanggerang Selatan.

Erlina Ambarwati, (2012), Pendahuluan: Pengertian Agronomi Dan Hortikultura Beserta Ruang Lingkupnya. Bahan Ajar Mata Kuliah DasarDasar Agronomi D, Fakultas Pertanian, UGM, Yogyakarta.

Mega Ratri Ayu Aksani, (2017), Analisis Strategi Dan Manajeman Ekspor Produk Hortikultura Di Pt. Bumi Sari Lestari Temanggung, Doctoral Dissertation, Universitas Muhammadiyah Semarang.

\section{E. Karya Pengabdian Lepas} (Website)

Priguna, S. (2012). Path, Jejaring Sosial Baru yang Menyenangkan Chip.

Diakses 
dari:http://chip.co.id/news/gene

$\mathrm{ral} / 2690 /$ path_jejaring_sosial_

baru_yang_menyenangkan

pada 21 Oktober 2017. 